\title{
Growth-promoting factors in malt distillers dried solubles
}

\author{
Field trials and preliminary findings \\ BY J. A. WAKELAM \\ The Distillers Company (Biochemicals) Ltd, Broadway House, \\ The Broadway, Wimbledon, London, S.W. I9 \\ AND W. P. JAFFE \\ School of Veterinary Science, University of Bristol
}

(Received 2 fuly 1957-Revised I8 October 1957)

The dried solubles from maize distillers in the United States have long been used as ingredients of feeding-stuffs. Their protein content and high levels of $\mathrm{B}$ vitamins were originally the principal reasons for their inclusion in poultry mashes, but in recent years attention has been concentrated on the unidentified growth factor(s) they appear to contain.

Numerous workers have investigated the factor(s) and probably the first report was that of Synold, Carrick, Roberts \& Hauge (1943 $a, b$ ). The Purdue group (Novak \& Hauge, I948) later announced their isolation of the unidentified growth factor in distillers dried solubles, with the rat as experimental animal, and proposed the name vitamin $B_{13}$. Further work, however, has revealed a much more complicated situation, and it now seems likely that unidentified growth factors exist in distillers dried solubles, dried whey, fish solubles, fermentation residues, liver fractions, grass juice and possibly other common ingredients of feeding-stuffs. The possibility that part of the response to sources of unidentified growth factors is due to their mineral content has been investigated in Texas by Dannenburg, Reid, Rozacky \& Couch (1955) and at Cornell by Morrison, Scott \& Norris (1955) and Morrison, Dam, Norris \& Scott (1956). We have investigated this aspect, in so far as it relates to our more practical conditions, and have found that under such conditions the response to the ash of malt distillers solubles appears to be due to manganese (Jaffe \& Wakelam, 1958). O'Dell \& Savage (1957) have suggested that zinc may also be involved, and it seems that the warnings of Briggs (1956) were apposite in this matter. Apart from this possible contribution by the inorganic fractions of the various sources of unidentified factors, the extensive literature on the responses to the organic fractions is somewhat confused as to the identity or otherwise of the factors provided by the several materials. Numerous attempts have been made to clarify the issues involved, including reviews by Menge, Combs, Hsu \& Shorb (1952), Combs, Sweet, Jones, Romoser \& Bishop (1954), Norris (1954, 1955), and Couch, Kurnick, Svacha \& Reid (1957). In the latest review from the Cornell group Scott (1957) differentiates five factors: fishsolubles factor (A), fermentation-solubles factor (B), grass-juice factor (C), mineral factor (D) and protein factor (E). It is suggested that distillers solubles provide $B$ 
and $\mathrm{D}$, whereas fish solubles provide $\mathrm{A}, \mathrm{B}$ and $\mathrm{D}$, and whey $\mathrm{A}, \mathrm{C}$ and $\mathrm{D}$. This arrangement, however, is not generally accepted, and a paper by Rasmussen, Luthy, Van Lanen \& Boruff (I957), that appeared at about the same time, suggests the presence of three factors, designated liver, distillers solubles and whey; though indicating that most sources probably include lesser amounts of other factors, these workers evidently consider that fish solubles provide only the liver factor.

The lack of agreement between various workers may, as Briggs (I956) has suggested in connexion with the ash response, be due to differences in the nutrients provided by the basal diets used. On the other hand, as Rasmussen et al. (1957) have pointed out, the energy level of the diets used may well influence results. Taking Rasmussen's point further, however, we consider that much of the difficulty may well be caused by the fact that we are dealing with factors only coming into significance under particular conditions. It has formerly been considered that today's unidentified factors are tomorrow's vitamins, but it is probable that with vitamin $B_{12}$ and folic acid we reached the end of the list of vitamins in the generally accepted sense of 'micronutrients required for normal growth'. The factors now being studied might be more properly described as 'micronutrients required for supernormal growth', and we suggest a new term to describe them, such as 'hyperbolites'. Such factors are required only when the bird or animal is being induced by diets of very high energy, or by genetic selection, to grow or produce at an exceptional rate or is subjected to some other metabolic stress. Under such conditions it is to be expected that the metabolism will be modified, so that, apart from the need for higher-than-normal levels of known vitamins, modified metabolic pathways may require the 'hyperbolites' to which we have referred. The synthetic diets and special conditions used in most work on unidentified factors will themselves constitute a metabolic stress, and the rapid-growing broilers and turkeys, for which sources of unidentified growth factors are used, are certainly maintained under conditions of stress. Under such conditions not only the emergence of new unidentified growth factors (or 'hyperbolites') but also considerable variation in response to them is to be expected.

The isolation of solubles from the spent wash from malt-whisky distillation has only recently been developed; as it seemed probable that, like maize distillers solubles, they would contain unidentified growth factor(s) the present studies were undertaken. The results will not be directly comparable with those of the American workers because of certain differences between the American and Scottish whisky industries. (1) The 'mash bill' for the malt whisky is $100 \%$ barley malt. U.S. Bourbon-mash bills are typically $85 \%$ maize, $15 \%$ malt, although the percentages differ between distilleries. (2) After 'mashing' the whole mash is fermented in the Bourbon process, whereas the bulk of the solid material is removed before fermentation in the 'Scotch' process. (3) The yeasts used for fermentation differ. (4) Distillation of malt-whisky spirit is batchwise in pot-stills, whereas most Bourbon is continuously distilled.

The products differ in contents of known nutrients; in general the malt distillers solubles have higher protein and much higher $\mathrm{B}$-vitamin values than the maize distillers products. 
PART I. FIELD TRIALS

In order to obtain a preliminary assessment of the material a number of field trials were undertaken in which malt distillers dried solubles were included in commercial rations fed under normal farm conditions. In most of these the growth responses obtained suggested that the solubles contained some factor capable of improving the early growth of chicks and poults being maintained on rations assumed to be adequate.

\section{Experimental and results}

The I I,000 chicks of a strain bred for rapid growth and intended to be killed for table use at about 13 weeks (broilers) were housed in a single building and divided by wire-netting partitions into two equal groups. One group received a special broiler feed which had formerly given good results. This food provided approximately $22 \%$ protein and included $10 \%$ fish meal, $2.5 \%$ grass meal and $2.5 \%$ dried skim milk. High levels of vitamin $A$, vitamin $D_{3}$, riboflavin, pantothenic acid, nicotinic acid and $\alpha$-tocopherol were included as also were penicillin, arsenic acid and nitrofurazone. A trace-element mineral mix was included. The second group received $2 \cdot 5 \%$ distillers dried solubles in place of the dried skim milk. By minor adjustments of the constituents, the bulk analysis and the vitamin levels were all equated. Sample weighings of the birds were made at weekly intervals for 6 weeks with the results shown below (mean weights in $\mathrm{g}$ ):

\begin{tabular}{|c|c|c|c|c|c|c|c|}
\hline & \multicolumn{7}{|c|}{ Week } \\
\hline & 3 & 4 & 5 & 6 & 7 & 8 & 9 \\
\hline Normal ration & 227 & 395 & 522 & $68 \mathrm{I}$ & 981 & $I \simeq 35$ & 1407 \\
\hline Ration with solubles & 232 & 409 & 545 & $68 \mathrm{I}$ & 999 & II 35 & I 453 \\
\hline
\end{tabular}

Though the differences were not large they appeared to be fairly consistent throughout.

Two groups, each of 200 turkey poults, were given a high-grade proprietary starter feed in the form of 'crumbs' and a feed produced by replacing $2.5 \%$ dried skim milk in the standard product by distillers dried solubles and equating the bulk analysis and vitamin levels by minor adjustments as necessary. In addition to the $2.5 \%$ dried skim milk, the proprietary feed (which provided about $25 \%$ total protein) contained $7.5 \%$ fish meal, $3 \%$ dried grass and $2 \%$ dried yeast. Vitamin levels were all more than adequate by current standards and the ration contained penicillin. The birds were housed under identical normal commercial conditions and the mortality, which was low, was the same in both groups. Feathering was good, but appeared slightly better in the group receiving solubles. The birds were weighed, as two groups, at day-old and at 8 weeks, with the following results:

\begin{tabular}{lccccc} 
& \multicolumn{3}{c}{ Mean weight $(\mathrm{g})$} & Increase & $\begin{array}{c}\text { Food-conversion } \\
\text { efficiency } \\
\text { (g food/g weight } \\
\text { increase) }\end{array}$ \\
Proprietary feed & 54.5 & 1561 & 1506 & 2.70 \\
Feed with solubles & 54.5 & 1596 & 1562 & 2.64
\end{tabular}


In a further broiler trial, fifty birds in each of two groups, under identical conditions on the same farm, were given rations which differed only in that in one group $5 \%$ solubles were added at the expense of $5 \%$ barley. The original (commercial) ration contained already all the usual ingredients, including fish meal, grass meal and yeast and was fortified by additional vitamins and antibiotics. The birds were weighed individually at day-old, 4 weeks, 8 weeks and 12 weeks, with the following results:

\begin{tabular}{lcccc} 
& \multicolumn{4}{c}{ Mean weight $(\mathrm{g})$} \\
Proprietary mash & $\overbrace{\text { Pay-old }}$ & 4 weeks & 8 weeks & 12 weeks \\
Mash with solubles & 40 & 254 & 810 & 1498 \\
& 40 & 280 & 831 & 1631
\end{tabular}

Statistical analysis of the individual weights gave standard errors of the means of $8.4,19.6$ and $33.7 \mathrm{~g}$ respectively at 4,8 and 12 weeks. As the birds were allocated at random from the same batch and were housed in adjoining identical pens, we considered it justifiable to use these standard errors to assess the significance of the response shown. On this basis the response to solubles was significant at the $0 \cdot 1 \%$ level at $\mathrm{I} 2$ weeks. We are unable to account for the small response (not significant) at 8 weeks.

From these and other field trials with chicks, turkeys, calves (preruminant) and young pigs, it seemed probable that the dried solubles contributed some growthpromoting factor(s) not provided by standard feed ingredients such as fish meal, yeast, whey and grass meal. The limitations of practical trials are well known, and more closely controlled investigations were made.

PART 2. LABORATORY TRIALS

\section{Experimental}

Rhode Island Red $\times$ Light Sussex cockerels from ordinary hatchery stock were used in all experiments except when stated otherwise. Because of their origin it can be assumed that their dams were given diets fortified with unidentified factors. Rasmussen et al. (1957) have observed that little is gained by depletion of the dams, and throughout this work we have endeavoured to keep as close to practical conditions as is consistent with experimental control. The birds were housed on wire floors in two four-tier brooders, the tiers being divided longitudinally so as to provide sixteen separate compartments each capable of housing twenty-five chicks to 4 weeks. The effect of position was investigated in early trials by the use of a $4 \times 4$ Latin-square layout, but analysis indicated that positional effect was small (Jaffe \& Wakelam, 1958) and in later experiments we have used an $8 \times 2$ randomized block design.

The chicks were weighed and wing-banded on arrival (either I or 2 days from hatching) and were then distributed at random between the sixteen compartments. Thereafter they were weighed at I, 2, 3 and 4 weeks of age and on the same days food consumption was recorded for each compartment. Wastage was virtually eliminated by the design of the feeding troughs and by ensuring that only a small amount of food was available. Ordinary tap water was provided in the drinking troughs. In developing the basal diet (see Table I) used in our work we did not attempt to exclude all sources 
of unidentified growth factors, but merely to formulate a ration that, while providing ample levels of all known vitamins and supporting growth rates not less than normal, would nevertheless prove capable of improvement by the addition of distillers solubles. In order to ensure that the protein of the solubles (over $30 \%$ ) did not influence growth, we used a high level of protein in the basal diet. This arrangement also enabled us, by the inclusion of $15 \%$ gelatin, to ensure adequacy of essential aminoacids, notably arginine, which, as has recently been pointed out (Hogan, Craghead, Savage, Cole \& O'Dell, 1957), is frequently inadequate for optimal growth in diets

Table I. Standard diet for growth-factor work on chicks

\begin{tabular}{lr}
\multicolumn{2}{c}{ Basal diet } \\
Casein (\%) & 25 \\
Gelatin (\%) & 15 \\
Maize starch (\%) & 29 \\
Sucrose (\%) & 10 \\
Lard (\%) & 10 \\
Distillers dried grains (\%) & 5 \\
Mineral mix (\%) & 6
\end{tabular}

\begin{tabular}{lc}
\multicolumn{2}{c}{ Additions } \\
Cystine (\%) & $0 \cdot 25$ \\
Vitamin A (i.u./lb.) & 4000 \\
Cholecalciferol (i.u./lb.) & 1000 \\
$\alpha$-Tocopheryl acetate (mg/lb.) & $4 \cdot 5$ \\
Menaphthone (mg/lb.) & $2 \cdot 0$ \\
Cyanocobalamin (mg/lb.) & $0 \cdot 008$ \\
Thiamine hydrochloride (mg/lb.) & $\mathrm{r} \cdot 6$ \\
Riboflavin (mg/lb.) & $2 \cdot 6$ \\
Calcium pantothenate (mg/lb.) & $8 \cdot 4$ \\
Nicotinic acid (mg/lb.) & $24 \cdot 0$ \\
Choline chloride (mg/lb.) & $\mathrm{I} 200 \cdot 0$ \\
Pyridoxine hydrochloride (mg/lb.) & $2 \cdot 6$ \\
Biotin (mg/lb.) & $0 \cdot 08$ \\
$p$-Aminobenzoic acid (mg/lb.) & $2 \cdot 6$ \\
Inositol (mg/lb.) & $450 \cdot 0$ \\
Folic acid (mg/lb.) & 0.5 \\
Procaine benzylpenicillin (mg/lb.) & $4 \cdot 0$
\end{tabular}

Mineral mix

Any additions were made at the expense of maize starch

\begin{tabular}{|c|c|c|c|}
\hline \multicolumn{4}{|c|}{ Mineral mix } \\
\hline \multirow[b]{2}{*}{$\mathrm{CaCo}_{3}(\%)$} & \multirow{2}{*}{$\begin{array}{c}\text { Amount } \\
9.55\end{array}$} & \multicolumn{2}{|c|}{$\begin{array}{l}\text { Contribution to basal diet } \\
\text { when added at } 6 \%\end{array}$} \\
\hline & & $\mathrm{Ca}(\%)$ & $\mathrm{I} \cdot 005$ \\
\hline Steamed bone flour $(22 \% \mathrm{Ca}$, I $7 \% \mathrm{P})(\%)$ & $50 \cdot 00$ & $\mathrm{P}(\%)$ & 0.600 \\
\hline $\mathrm{CaH}_{4}\left(\mathrm{PO}_{4}\right)_{2} \mathrm{H}_{2} \mathrm{O}(\%)$ & 6.60 & Ratio, $\mathrm{Ca}: \mathrm{P}$ & $1 \cdot 67$ \\
\hline $\mathrm{KCl}(\%)$ & 10.42 & $\mathrm{~K}(\%)$ & 0.33 \\
\hline $\mathrm{NaCl}(\%)$ & $12 \cdot 22$ & $\mathrm{NaCl}(\%)$ & 0.73 \\
\hline $\mathrm{MgSO}_{4}(\%)$ & $6 \cdot 38$ & $\mathrm{Mg}$ (mg/lb.) & 225 \\
\hline $\mathrm{MnSO}_{4} \cdot 4 \mathrm{H}_{2} \mathrm{O}(\%)$ & $2 \cdot 78$ & $\mathrm{Mn}(\mathrm{mg} / \mathrm{lb})$. & I 85 \\
\hline $\mathrm{ZnCl}_{2}(\mathrm{~g} / \mathrm{1} 00 \mathrm{lb})$. & 12 & $\mathrm{Zn}(\mathrm{mg} / \mathrm{lb})$. & $3 \cdot 45$ \\
\hline$K I(g / 100 \mathrm{lb})$. & 25 & I (mg/lb.) & I I \\
\hline $\mathrm{H}_{3} \mathrm{BO}_{3}$ (g/100 lb.) & 6 & $\mathrm{~B}(\mathrm{mg} / \mathrm{lb})$. & 0.8 \\
\hline $\mathrm{CoSO}_{4} \cdot 7 \mathrm{H}_{2} \mathrm{O}$ (g/10o lb.) & 6 & $\mathrm{Co}(\mathrm{mg} / \mathrm{lb})$. & 0.8 \\
\hline $\mathrm{CuSO}_{4} \cdot 5 \mathrm{H}_{2} \mathrm{O}$ (g/100 lb.) & 67 & $\mathrm{Cu}(\mathrm{mg} / \mathrm{lb})$. & 12 \\
\hline $\mathrm{FeSO}_{4} \cdot 7 \mathrm{H}_{2} \mathrm{O}(\mathrm{g} / 100 \mathrm{lb})$. & 880 & Fe (mg/lb.) & 120 \\
\hline
\end{tabular}

based on casein. Because of this high level of protein and to ensure rapid growth, we found it necessary to add lard to raise the energy level of the diet. All known vitamins were added at levels considerably in excess (usually double) the recommendations of the (U.S.A.) National Research Council: Committee on Animal Nutrition (1954). Calculations revealed that in the final diet all essential amino-acids were present at levels above those recommended by the National Research Council, after appropriate correction for the higher protein levels. To prevent the development of rancidity the diets were made up freshly each week. 
In our earlier experiments (Jaffe \& Wakelam, 1956) we used a 40:60 mixture of dried solubles and 'dried distillery grains' because of the hygroscopic nature of the solubles. It has been explained above that in the malt-whisky process the 'grains' are removed after mashing and before fermentation, in contrast to the American method. Because of this the 'grains' are simply the insoluble portions of the original barley malt, and as such can be assumed to be free from growth-factor activity. They were used in the earlier work to balance the diets and as a convenient source of roughage. As they proved satisfactory for this purpose, they have been retained in the current basal diet.

The manganese level of the basal diet was fixed at the high level of $185 \mathrm{mg} / \mathrm{lb}$. because of the response to the ash of distillers solubles (Jaffe \& Wakelam, I958). At this higher level we obtain no response to the ash. This is not to suggest that a response similar to those of Morrison et al. (1955, 1956) and others might not have resulted from such rigid conditions as those used by the Cornell workers in their later work (Morrison et al. 1956). Our casein was not specially washed, the dried distillers grains no doubt provided a variety of trace minerals, we used tap water for drinking and we did not deplete the dams of our chicks.

In this work we have been concerned principally with growth factors likely to be of significance in practical poultry husbandry, and we did not, therefore, consider such techniques suitable.

In several experiments to check different aspects of the basal diet, as a result of which the formula given in Table $\mathrm{I}$ was arrived at, we consistently obtained better growth when distillers dried solubles were added, although the extent of the improvement was variable. We also showed that the alkali treatment, which had been found necessary to counteract the hygroscopic nature of the dried solubles and to produce a free-flowing product, had no effect upon any factor causing the growth promotion (Jaffe \& Wakelam, 1956).

It was thought that two other distillery by-products might be of interest in this study. These were dried distillery concentrates and acetone-butanol residues. The first is produced by drying the centrifuged solids from whisky distillation spent wash, and the second is obtained by drying the bacterial solids recovered centrifugally from the acetone-butanol fermentation spent wash. The standard basal diet was used in two control groups and the other six diets were made up at two levels $(3 \%$ and $6 \%)$ of each product.

\section{Results}

The results of the experiment in which the additions of distillers dried solubles, dried distillery concentrate and acetone-butanol residues to the basal diet were studied are shown in Table 2.

Analyses of variance were carried out for weight increases and food conversion.

The standard errors quoted in this and all the other tables are those of single-pen means and are calculated from the interactions between brooders and treatments.

After this experiment we concentrated attention on the solubles, although we intend to study other by-products further at a later date. The results of a series of experiments 
in which different levels of distillers dried solubles were used are summarized in

Table 3 .

In all the experiments quoted in Table 3 , penicillin was included in the basal diet which was exactly as shown in Table I. In Exp. C (Table 3 ) pullets were used but in

Table 2. Mean weight increases $(g$ ) and food-conversion efficiencies ( $g$ food/g weight increase) of chicks given some distillery by-products in addition to a standard diet

(Twenty-five chicks/subgroup)

\begin{tabular}{|c|c|c|c|c|c|c|c|c|c|c|}
\hline \multirow[b]{2}{*}{ Diet } & \multirow[b]{2}{*}{$\begin{array}{l}\text { No. of } \\
\text { sub- } \\
\text { groups }\end{array}$} & \multirow[b]{2}{*}{$\begin{array}{l}\text { Initial } \\
\text { weight }\end{array}$} & \multicolumn{2}{|c|}{ After I week } & \multicolumn{2}{|c|}{ After 2 weeks } & \multicolumn{2}{|c|}{ After 3 weeks } & \multicolumn{2}{|c|}{ After 4 weeks } \\
\hline & & & $\begin{array}{l}\text { Weight } \\
\text { increase }\end{array}$ & $\begin{array}{c}\text { Food- } \\
\text { conversion } \\
\text { efficiency }\end{array}$ & $\begin{array}{l}\text { Weight } \\
\text { increase }\end{array}$ & $\begin{array}{l}\text { Food- } \\
\text { conversion } \\
\text { efficiency }\end{array}$ & $\begin{array}{l}\text { Weight } \\
\text { increase }\end{array}$ & $\begin{array}{c}\text { Food- } \\
\text { conversion } \\
\text { efficiency }\end{array}$ & $\begin{array}{l}\text { Weight } \\
\text { increase }\end{array}$ & $\begin{array}{c}\text { Food- } \\
\text { conversion } \\
\text { efficiency }\end{array}$ \\
\hline Control & 4 & $39 \cdot 0$ & $43 \cdot 4$ & $I \cdot I 4$ & I 18 & $I \cdot 3 I$ & $23^{\circ}$ & $I \cdot 36$ & 374 & $1 \cdot 52$ \\
\hline $3 \%$ DDS & 2 & $39 \cdot 3$ & 49.4 & $x \cdot 26$ & $132^{*}$ & $I \cdot 42$ & 234 & $I^{*} 49^{*}$ & 388 & I.55 \\
\hline $6 \%$ DDS & 2 & $39 \cdot 2$ & $51 \cdot 6 \dagger$ & I.06 & $137^{*}$ & $\mathrm{I} \cdot \mathbf{2 8}$ & $25^{8 *}$ & I.34 & $408^{*}$ & 1.47 \\
\hline $3 \%$ DDC & 2 & 38.8 & $46 \cdot 0$ & $1 \cdot 07$ & 124 & $I \cdot 34$ & 243 & $I \cdot 34$ & $38 r$ & 1.48 \\
\hline $6 \%$ DDC & 2 & $38 \cdot 4$ & $46 \cdot 4$ & 1.05 & 130 & $I \cdot 3 I$ & 233 & $I \cdot 43$ & 382 & $\times 57$ \\
\hline $3 \% \mathrm{AB}$ & 2 & $38 \cdot 8$ & 44.9 & $r \cdot 06$ & II9 & $I \cdot 29$ & $23^{6}$ & $I \cdot 3 I$ & $3^{64}$ & I.49 \\
\hline$\% \mathrm{AB}$ & 2 & 39.4 & $46 \cdot 4$ & $x \cdot 30$ & 119 & $I \cdot 45$ & 236 & $I \cdot 42$ & $37^{\circ}$ & $I \cdot 64$ \\
\hline Standard & of & & $\pm 4 . I$ & \pm 0.157 & $\pm 7 \cdot 0$ & \pm 0.088 & \pm 10.3 & \pm 0.057 & $\pm \mathrm{I}_{5}$ & \pm 0.068 \\
\hline
\end{tabular}

* Difference from controls significant at the $5 \%$ level.

+ Difference from controls bordering on significance at the $5 \%$ level.

DDS, distillers dried solubles; DDC, distillers dried concentrate; $\mathrm{AB}$, acetone-butanol residues.

Table 3. Mean weight increases ( $g$ ) of chicks given different levels of distillers dried solubles in addition to a standard diet

(Twenty-five chicks/subgroup)

\begin{tabular}{|c|c|c|c|c|c|c|c|}
\hline \multirow{3}{*}{$\begin{array}{c}\text { Exp. no. } \\
\text { A }\end{array}$} & \multirow{2}{*}{$\begin{array}{c}\text { DDS } \\
\text { level } \\
(\%)\end{array}$} & \multirow[b]{2}{*}{$\begin{array}{c}\text { No. of } \\
\text { subgroups }\end{array}$} & \multirow[b]{2}{*}{$\begin{array}{l}\text { Initial } \\
\text { weight }\end{array}$} & \multicolumn{4}{|c|}{ Weight increase after } \\
\hline & & & & I week & 2 weeks & 3 weeks & 4 weeks \\
\hline & o & 4 & $37 \cdot 4$ & $5 x \cdot 6$ & 135 & 247 & 369 \\
\hline & 3 & 2 & $39 \cdot 2$ & $58 \cdot 8$ & $15^{*}$ & $270^{*}$ & $39 I^{*}$ \\
\hline & 6 & 2 & $35^{\cdot} 6$ & $52 \cdot 2$ & 140 & 256 & $3^{81}$ \\
\hline $\mathrm{B}$ & 0 & 4 & $39^{\circ} \circ$ & $43 \cdot 4$ & 118 & 230 & 374 \\
\hline & 3 & 4 & $39 \cdot 3$ & $49 \cdot 3$ & $133^{*}$ & 235 & 389 \\
\hline & 6 & 4 & $39 \cdot 2$ & $51 \cdot 7$ & $138 *$ & $259^{*}$ & $409^{*}$ \\
\hline $\mathrm{C}$ & $\circ$ & 4 & $40 \cdot 6$ & $35 \cdot 8$ & 99 & I93 & 299 \\
\hline & 6 & 2 & $4 I \cdot 5$ & 38.4 & I I $2^{*}$ & $212^{*}$ & $328 *$ \\
\hline $\mathrm{D}$ & 0 & 2 & $39 \cdot 8$ & $39 \cdot 4$ & 109 & 228 & 374 \\
\hline & 2 & 2 & $43^{\circ} \circ$ & $35 \cdot 3$ & 109 & 228 & 371 \\
\hline & 4 & 2 & $4 I \cdot 6$ & $32 \cdot 6$ & 112 & 233 & 377 \\
\hline & 6 & 2 & $41 \cdot 6$ & $4 I \cdot 2$ & 117 & 245 & 390 \\
\hline & ro & 2 & $39^{\circ} 0$ & 40.4 & $120^{*}$ & 238 & 391 \\
\hline $\mathbf{E}$ & $\circ$ & 2 & $36 \cdot 7$ & $42 \cdot 6$ & I3I & 255 & 410 \\
\hline & 4 & 2 & 36.0 & $50.5^{*}$ & $148^{*}$ & $279^{*}$ & $435^{*}$ \\
\hline & 5 & 2 & $36 \cdot 6$ & $47^{\circ} 6^{*}$ & $146 *$ & $28 I^{*}$ & $446^{*}$ \\
\hline & 6 & 2 & $35^{\cdot 6}$ & $47 \cdot 3^{*}$ & $146 *$ & 274 & 426 \\
\hline & 7 & 2 & $36 \cdot 4$ & $48 \cdot 0^{*}$ & $148^{*}$ & $280^{*}$ & $43 I$ \\
\hline & 8 & 2 & $36 \cdot 2$ & $48 \cdot 4^{*}$ & $147^{*}$ & 275 & 434 \\
\hline$F$ & 0 & 2 & $38 \cdot 0$ & $35 \cdot 4$ & II 5 & 260 & 398 \\
\hline & 3 & 2 & $37 \cdot 9$ & $40.7^{*}$ & $135^{*}$ & 284 & 425 \\
\hline & 4 & 2 & $37 \cdot 6$ & $40 \cdot 6$ & 129 & 282 & 423 \\
\hline & 5 & 2 & $37^{\circ} 2$ & $39^{\circ} \mathrm{I}$ & 126 & 277 & 415 \\
\hline & 6 & 2 & $37 \cdot 8$ & $46 \cdot 2^{*}$ & $137^{*}$ & $289^{*}$ & $429^{*}$ \\
\hline & 7 & 2 & $37 \cdot 6$ & $46 \cdot 2^{*}$ & $143^{*}$ & $302^{*}$ & $43^{6 *}$ \\
\hline
\end{tabular}


all other experiments quoted in Table 3 and elsewhere we used exclusively cockerels. All other conditions were identical and were as detailed above. Exps. D-F were carried out after the transfer of the brooders to a new house. In Exps. E and F the effect of penicillin was also studied, and the full results of these experiments are shown in Table 5 (first and second experiments, respectively). These results are discussed in detail below, but it is of interest to note here that, though no significant response was obtained from the addition of penicillin in Exp. E, a response to penicillin significant at the $5 \%$ probability level was shown in Exp. F. In Table 3 only the results with diets containing penicillin are shown so that they may be compared with results, given in the table, of the other experiments, in all of which penicillin was included in all diets.

\begin{tabular}{|c|c|c|c|c|}
\hline \multirow{2}{*}{$\begin{array}{l}\text { DDS } \\
\text { level } \\
(\%)\end{array}$} & \multicolumn{4}{|c|}{ Weight increase after } \\
\hline & I week & 2 weeks & 3 weeks & 4 weeks \\
\hline$\circ$ & $4 \mathrm{I} \cdot 7$ & II9 & 237 & 373 \\
\hline 2 & $4 I \cdot 3$ & 123 & 242 & 376 \\
\hline 3 & $48 \cdot 4$ & ×33 & $25 \mathrm{I}$ & 390 \\
\hline 4 & $44 \cdot 3$ & 128 & 250 & 388 \\
\hline$=$ & $43 \cdot 0$ & 127 & $25 \mathrm{I}$ & 393 \\
\hline 6 & $45^{\circ} 6$ & I3I & 255 & 393 \\
\hline 7 & $46 \cdot 8$ & I36 & 265 & 396 \\
\hline 8 & $45 \cdot 5$ & 132 & 253 & 393 \\
\hline 10 & $46 \cdot 3$ & 134 & 252 & 396 \\
\hline
\end{tabular}

In an attempt to arrive at valid conclusions from the several experiments summarized in Table 3, the principle of fitting constants (see, for example, Yates, 1933) was used to provide mean results at each experimental level. These means are shown in Table 4 .

Table 5 shows the growth results and gives information on food efficiency in two experiments which included groups without the normal penicillin supplement. These experiments were begun after the transfer of the brooders to a new house when it was found that a lower response was obtained to distillers dried solubles (cf. Table 3 , Exp. D).

\section{DISCUSSION}

From the various results presented here and elsewhere (Jaffe \& Wakelam, 1956, 1958) it can be stated that distillers dried solubles stimulate a growth response in chicks maintained under good conditions and receiving a diet complete in all known nutrients.

The results, especially those in Tables 3 and 4 , show that the response is somewhat variable, but that it is usually statistically significant. The averaging of various results to give the information in Table 4 has tended to reduce the apparent magnitude of the response because of the inclusion of some apparently aberrant results. The overall response appears, however, to be of the order of $6-7 \%$. Although there is no clear maximum, the greatest increase seems to take place at levels of addition between 2 


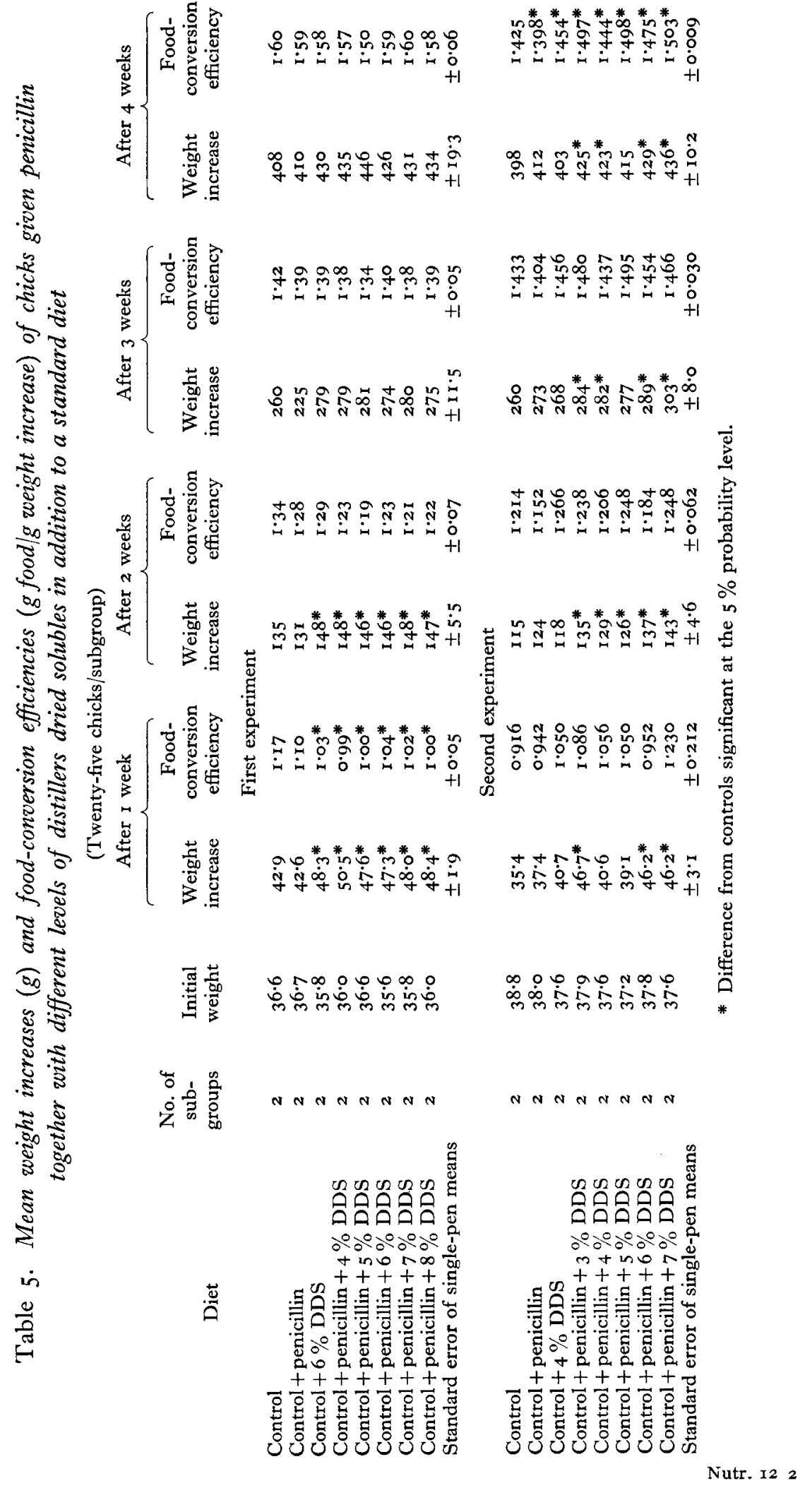


and $3 \%$. Above that further increases are not significant. It is worth noting that the growth rates obtained on the control diet are already some $50 \%$ higher than those obtained with chicks from the same hatching fed on commercial broiler rations, which leads us to conclude that the response is one of practical significance.

The other by-products studied did not appear to provoke a similar response under the conditions used, which is at variance with experience in field trials; we propose to examine these materials again at a later date.

The variable results, despite closely controlled conditions and the fall in response by improved growth of the control birds when the brooders were moved to a new house (see Table 3, Exp. D), were very reminiscent of the effects of antibiotic supplementation. The obvious similarity to the findings reported by Coates, Dickinson, Harrison, Kon, Porter, Cummins \& Cuthbertson (1952) and others with penicillin in 'clean' and 'dirty' houses, led us to investigate the influence of penicillin (see Table 5). Until these two experiments, our diets had all included penicillin, as detailed in Table $\mathrm{r}$. It will be seen that in the second experiment in the new house (first experiment in Table 5) the effect of penicillin was negligible, whereas that of distillers dried solubles, although less than in earlier experiments, was highly significant. In the third experiment in the new house (second experiment in Table 5) the response to penicillin reached significance $(P<0.05)$ at 2 weeks and bordered on significance $(P<0.06)$ at 3 and 4 weeks. The distillers dried solubles failed to give a significant response alone, but in the presence of penicillin the responses were highly significant, compared with those of the control birds both with and without penicillin.

These results lead us to suspect that the distillers dried solubles may be acting at least in part through the intestinal flora of the birds, in the same way as penicillin is believed to act. Direct investigations of the intestinal flora are in progress and appear to support this view. We also hope to investigate other alleged sources of unidentified factors, both directly by growth trials and indirectly by studying intestinal flora, in an effort to obtain more information on the nature and mechanism of their growthpromoting activity. It seems possible that modification of intestinal flora may be a general method of growth promotion and, if so, the confusion which at present exists about various supposed sources of unidentified factors is not surprising. A fuller understanding of this matter would go far to rationalizing not only the scientific position concerning new growth factors (or 'hyperbolites' as we have suggested they may be called) but also the general practice of formulation of animal feeds. This latter point is of some importance since it is already well known that various feed ingredients and combinations of them sometimes have effects on growth which cannot be fully explained in terms of the nutrients which they supply. It has long been considered that skim milk has an effect upon the intestinal flora, which effect is believed to account for some of the nutritive value of milk. The probably indirect nature of the growth-stimulating effect of lactose in a complete synthetic diet for chicks was referred to by Briggs \& Spivey (1954). A broader understanding of the effects of intestinal flora in nutrition may well be of considerable importance in future attempts to reduce the cost of animal feeding. 


\section{SUMMARY}

r. Field trials with chicks and turkeys have shown that the addition of malt distillers dried solubles at levels of about $5 \%$ to practical diets complete in all known nutrients leads to increased growth. Three such trials are reported. As a result of these, laboratory work was done and is reported in detail.

2. A standard diet of semi-purified ingredients and containing all known nutrients at high levels has been developed. This diet was used in all the work reported and gave consistent growth responses of the order of $6-7 \%$ when distillers solubles were added.

3. In the experiments reported groups of twenty-five male Rhode Island $\times$ Light Sussex chicks were taken from day-old to 4 weeks and fed $a d l i b$. There were sixteen such groups (eight to each of two four-tier brooders) in each experiment, and the usual arrangement was to test eight modifications of the standard diet by an $8 \times 2$ randomized block arrangement. Statistical analysis was made of all results and the growth response to distillers solubles was almost always significant at the $5 \%$ level.

4. Considerable variability of response was found to different levels of addition of distillers solubles, but it appears that an effective maximum response was obtained at a level somewhere between 2 and $3 \%$.

5. Other distillery by-products (dried distillery concentrate and acetone-butanol fermentation solids) did not appear to contain any unidentified factor present in malt distillers solubles.

6. Some similarity has been found between the response to solubles and to procaine penicillin, although the one supplemented the other. The effects upon these responses of removing the brooders to a new house have suggested a possibly similar mode of action.

We are indebted to Mr J. Ince, of the Research and Development Department, The Distillers Company Ltd, for his assistance with statistical analyses and to the Directors of the Distillers Company Ltd for financial assistance.

\section{REFERENCES}

Briggs, G. M. (1956). Poult. Sci. 35, 740 .

Briggs, G. M. \& Spivey, M. R. (1954). World's Poult. Congr. X. Edinburgh, p. 98.

Coates, M. E., Dickinson, C. D., Harrison, G. F., Kon, S. K., Porter, J. W. G., Cummins, S. H. \& Cuthbertson, W. F. J. (1952). F. Sci. Fd Agric. 3, 43.

Combs, G. F., Sweet, G. B., Jones, H. J., Romoser, G. L. \& Bishop, R. W. (1954). Poult. Sci. 33 , 1050.

Couch, J. R., Kurnick, A. A., Svacha, R. L. \& Reid, B. L. (1957). Proc. I2th Distillers Feed Research Conference, Cincinnati, p. $7 \mathbf{I}$.

Dannenburg, W. N., Reid, B. L., Rozacky, E. E. \& Couch, J. R. (I955). Poult. Sci. 34, roz3.

Hogan, A. G., Craghead, R. W., Savage, J. E., Cole, J. J. \& O’Dell, B. L. (1957). F. Nutr. 62, 97.

Jaffe, W. P. \& Wakelam, J. A. (1956). Nature, Lond., 178, 414.

Jaffe, W. P. \& Wakelam, J. A. (1958). Poult. Sci. (In the Press.)

Menge, H., Combs, G. F., Hsu, P. T. \& Shorb, M. S. (1952). Poult. Sci. 3r, 237.

Morrison, A. B., Dam, R., Norris, L. C. \& Scott, M. L. (1956). F. Nutr. 60, 283.

Morrison, A. B., Scott, M. L. \& Norris, L. C. (1955). Poult. Sci. 34, 738.

National Research Council: Committee on Animal Nutrition (1954). Publ. nat. Res. Coun., Wash., no. $30 \mathrm{I}$.

Norris, L. C. (1954). Proc. 9th Distillers Feed Research Conference, Cincinnati, p. 20. 
Norris, L. C. (1955). Proc. roth Distillers Feed Research Conference, Cincinnati, p. 39.

Novak, A. F. \& Hauge, S. M. (1948). F. biol. Chem. 174, 647.

O'Dell, B. L. \& Savage, J. E. (1957). Poult. Sci. 36, 459.

Rasmussen, R. A., Luthy, P. W., Van Lanen, J. M. \& Boruff, C. S. (1957). Poult. Sci. 36, 46.

Scott, M. L. (1957). Proc. 12th Distillers Feed Research Conference, Cincinnati, p. 61.

Synold, R. E., Carrick, C. W., Roberts, R. E. \& Hauge, S. M. (1943a). Poult. Sci. 22, 323.

Synold, R. E., Carrick, C. W., Roberts, R. E. \& Hauge, S. M. (1943b). Poult. Sci. 22, 336.

Yates, F. (1933). F. agric. Sci. 23, 108.

\title{
The influence of the route of administration on the effect of hexoestrol on fattening wether lambs
}

\author{
By T. R. PRESTON AND ISOLINE GEE* \\ Rowett Research Institute, Bucksburn, Aberdeenshire \\ (Received 22 fuly 1957-Revised I 3 fanuary 1958)
}

The administration of hexoestrol to livestock has been found by many workers to increase the rate of live-weight gain. It has been shown that hexoestrol treatment of lambs alters their metabolism in such a way that absorbed nutrients are diverted, in part, from fat anabolism to bone and muscle anabolism (Gee \& Preston, 1957). Since fat has a much higher calorific value per unit weight than either bone or muscle, and is generally stored with relatively little water, it follows that a given intake of food will produce a greater live-weight gain in a lamb treated with hexoestrol than in a lamb that has not been treated.

An increase in efficiency of conversion of food to live weight as a result of hexoestrol treatment has been reported by many investigators. More detailed carcass studies (Gee \& Preston, 1957) showed that treated lambs were 33\% more efficient in converting food protein to muscle protein but that efficiency of energy conversion was not affected by treatment. If these changes are desirable the findings would appear to justify the use of hexoestrol treatment in commercial lamb and mutton production (Preston \& Gee, 1957).

In our previous experiments treatment of lambs was mainly by subcutaneous implantation in the left ear of a single $15 \mathrm{mg}$ pellet of hexoestrol. In poultry one of the factors governing the rate of absorption of the hormone is the surface area of the pellet (Lorenz, 1954). Division of the standard $15 \mathrm{mg}$ pellet into three $5 \mathrm{mg}$ portions would be a possible way of increasing absorption without increasing the total dose.

Synthetic oestrogen may also be given by mouth in the food. Burroughs, Culbertson, Cheng, Hale \& Homeyer (1955) believe that objectionable side-effects, mainly slackening of the pelvic ligaments and mammary development, are less when cattle are fed stilboestrol than when the hormone is implanted subcutaneously.

\footnotetext{
* In receipt of a scholarship from the Ministry of Agriculture, Fisheries and Food.
} 